\title{
A five-point framework for reading for social justice: A case study of food and farming policy discourse in the context of Brexit Britain
}

\author{
Chris Maughan, ${ }^{\text {* }}$ Colin R. Anderson, a and Moya Kneafsey a \\ Centre for Agroecology, Water and Resilience. Coventry University
}

Submitted September 5, 2019 / Revised December 11, 2019, and January 7, 2020 / Accepted February 25, 2020 /

Published online May 18, 2020

Citation: Maughan, C., Anderson, C. R., \& Kneafsey, M. (2020). A five-point framework for reading for social justice: A case study of food and farming policy discourse in the context of Brexit Britain. Journal of Agriculture, Food Systems, and Community Development, 9(3), 281-300. https://doi.org/10.5304/jafscd.2020.093.024

Copyright (C) 2020 by the Authors. Published by the Lyson Center for Civic Agriculture and Food Systems. Open access under CC-BY license.

\begin{abstract}
Food justice represents an evolving framework that puts social justice at the center of debates on how to achieve sustainable food systems. Food justice has largely been examined in community-level projects and activism outside the UK. This paper uses food justice as a framework through which to analyze food policy discourse in the UK. Our analysis presents an approach to "reading for social justice" by using the twin pillars of "distributive" (how benefits and risks are shared) and "procedural" justice (who is included) as analytical lenses. We apply critical discourse analysis to 20 policy documents published since the 2016 "Brexit" referendum. Our analysis finds that elements of both distributive and

a Centre for Agroecology, Water and Resilience (CAWR), Coventry University; colin.anderson@,coventry.ac.uk

* Corresponding author: Chris Maughan. Centre for Agroecology, Water and Resilience. Coventry University; Priory Street; Coventry CV1 5FB UK; +44 (0) 247688 7688;

chris.maughan@,coventry.ac.uk
\end{abstract}

procedural justice are present, but underdeveloped or ignored across the documents. The lack of direct attention to social justice issues in the papers was not for lack of actual social justice issues, which were implicit within the discourse. The postBrexit discourse reproduced existing power imbalances and despite occurring at a juncture where the potential for change was high, marginalized and vulnerable voices remain underrepresented. In the context of post-Brexit Britain, as well as in any political context, we argue that if food policy-making and governance are to enable a more just and sustainable food system, a more systematic approach to incorporating social justice needs to be developed. To this end, we offer a five-part approach to "reading for social justice" when scrutinizing food and farming policy.

\section{Funding Disclosure}

This work was supported by an internal grant from the Centre for Agroecology, Water and Resilience, and a grant from the British Academy. 


\section{Keywords}

Brexit, Food Policy, Social Justice, Food Justice, Participation, Distributive Justice, Procedural Justice, Agricultural Policy

\section{Highlights}

- First systematic analysis of food policy discourse in UK in a food justice framework

- Social justice found to be only marginally present in post-Brexit policy debates

- Distributive and procedural justice needs much more attention in food policy

- Five-part framework for integrating food and social justice into policy analysis and policymaking processes

\section{Introduction}

There is growing concern over the place of food, agriculture, and food systems in society. How can we address the negative impacts of industrialized agriculture on the environment and health? How can changes in agriculture and food systems help cool the planet? And how can all this be done while addressing worsening social injustices that contribute to food insecurity and diet-related health inequalities affecting millions of people (Gottlieb \& Joshi, 2010; Holt-Giménez \& Shattuck, 2011)? Research and activism for more sustainable and socially just food systems have continually evolved, leading to many important practical and theoretical advances (Alkon \& Agyeman, 2011). Yet, the extent to which these advances are incorporated into different national food and farming policies remains uneven.

In this article, we focus on whether social justice has been reflected in recent debates on British food and farming policy, which have been stimulated by the United Kingdom's (UK) referendum on whether to withdraw from the European Union (colloquially known as "Brexit").

Brexit will have significant implications for the UK's food system, not least because it will mean the withdrawal of the UK from the Common Agricultural Policy, which has determined agriculture and rural development policy since 1973. While this rupture could be seen as an opportunity to advance more just and sustainable policies, it could also exacerbate existing problems in the food sys- tem related to environmental, economic, cultural, and social issues (Lang, Millstone, \& Marsden, 2017).

Brexit has prompted the articulation and public performance of political positions and recommendations from a range of interests concerned with Britain's food and farming sector. Since the referendum, dozens of documents have been published, setting out proposals for how the UK government should respond. These articulations present a unique opportunity to examine an important moment of discursive production; at moments of crisis, public debate can reveal both the constructed nature of current social norms, but also the "projections of possible states of affairs" or "possible worlds" (Chiapello \& Fairclough, 2002, p. 195). At this time of profound upheaval, as deep national divisions and social inequalities have been brought to the fore, we wanted to examine the extent to which public debates on food and farming have reflected similar concerns. In the complex world of food and agriculture policy, however, there is little guidance and no coherent framework for examining the processes by which social justice is articulated. To this end, this article develops and applies a framework designed to help "read for social justice" in order to analyze the extent to which current policy discourses engage with social justice issues in their framing, analysis, and proposals.

\section{Food Justice}

Food is deeply entangled with our wider economic, cultural, social, and ecological systems, touching many aspects of our lives. The problems in the dominant food systems in the UK both contribute to and reflect wider exploitative relations in society. This interdependence is often not obvious but remains implicit in our daily practices. A food justice approach applies a social justice lens to the food system, emphasizing how intersecting axes of oppression and privilege shape the experiences of differently positioned actors and groups (HoltGiménez \& Wang, 2011; Sbicca, 2018).

Food justice was first defined in the North American context (Levkoe, 2006), having emerged in part out of the longer-standing environmental justice movement (Alkon \& Agyeman, 2011). Food 
justice emphasizes how "just sustainability" (Agyeman, 2013) cannot be achieved without simultaneously challenging how unequal power relationssuch as issues of land ownership, labor exploitation, environmental and social injustices (amongst others) - play a central role in organizing the production, distribution, and consumption of food (Alkon \& Norgaard, 2009).

Food justice critiques not only the dominant food system, but also progressive initiatives that do not explicitly address these power dynamics and that often inadvertently reinforce them (Bradley \& Herrera, 2016). For example, organizations working on food are often led by privileged white activists and tend to focus on issues that reflect the interests of their middle-class proponents (Mama D \& Anderson, 2016; Wakeford, 2018), despite long histories of related activism by marginalized groups. ${ }^{1}$ Activist spaces, organizations, and networks thus risk becoming irrelevant for and/or excluding the voices and bodies of nondominant actors (Cadieux \& Slocum, 2015; Guthman, 2008). Despite a strong emphasis on environmentalism, many progressive efforts in the food movementhowever altruistic their intention-tend to gloss over difficult social justice issues that intersect with food systems, such as those related to labor rights, inequality, and privilege (Allen, FitzSimmons, Goodman, \& Warner, 2003). Food justice, at its core, entails a commitment to centering these power inequalities in the analysis and actions for food system change (Sbicca, 2018).

Food justice varies in different contexts and geographies and is most appropriately articulated in a place-based and context-specific approach (Moragues-Faus, 2017; Slocum, 2018); however, the particularities of these different experiences of food justice in different locations are only just beginning to be understood (Anderson, Bruil, Chappell, Kiss, \& Pimbert, 2019). Further, the concept of food justice has focused predominantly on analyzing the politics of grassroots community organizing and has only marginally been applied specifically in the context of policy (e.g., Horst, 2017). The goal of this paper is thus twofold. First, we ex- amine food justice in the UK, adding to the small body of literature on food justice in this context. Secondly, we examine food justice within the realm of policy and develop a framework for "reading for social justice" to evaluate policy discourse.

\section{Food Justice in the UK}

While issues related to the environment and public health are now gaining more prominence in debates on food and farming in the UK, issues of inequality, power imbalance, and social justice have received less attention. Food justice is most commonly invoked in relation to food poverty (or food insecurity), with campaigners and academics highlighting and problematizing the proliferation and institutionalization of food banks and other forms of charitable food provision as an increasingly entrenched part of the UK foodscape (Saxena \& Tornaghi, 2018). There is a considerable body of critical scholarship that advocates for a rightsbased approach to addressing food poverty (Dowler \& Jones Finer, 2003; Dowler \& LambieMumford, 2015), although this is not often situated within an explicit food justice framework.

Contemporary activism and organizing related to food in the UK are rarely framed in terms of either social justice or food justice but rather emphasize sustainability and health (Kneafsey, Owen, Bos, Broughton, \& Lennartsson 2017; Mama D \& Anderson, 2018). There are, however, growing numbers of UK-based community initiatives such as urban community gardens and urban farms that are adopting food sovereignty, food justice, the right to food, and other critical frameworks (Anderson et al., 2016). More specifically, small clusters of activists and scholars are directly and critically claiming the importance of social justice and working to bring issues around privilege, oppression, decoloniality, anti-racism, and gender transformation into the discourse on food and farming (e.g., Mama D \& Anderson, 2018).

\section{Frameworks for Reading for Justice}

There have been some efforts to propose different principles or tenets that underpin food justice. One

\footnotetext{
${ }^{1}$ For examples of related social justice activism by “marginalized” groups, see the Women's Environment Network (https://www.wen.org.uk) or Decoloniality London (https://www.decolonialitylondon.org)
} 
of the most cited approaches has been Cadieux and Slocum's (2015) proposal of four "nodes""trauma/inequity," "exchange," "land," and "labor" - around which the "doing" of food justice organizing occurs. Horst (2017), applies this fourpart framework to municipal planning policy in Washington State, updating it to include a fifth consideration that focuses on evaluating policies for democratic processes. This also resonates with Moragues-Faus's (2017) work examining food justice in media discourse in the UK, where participative justice emerges as an important, albeit weakly represented, aspect of discourse.

While helpful in terms of unearthing some key issues in grassroots activism, these dimensions arose out of a specific US-movement context. Thus, although these "nodes" are meant to hint at the key aspects or principles of food justice, they are arguably too specific to use as a lens to read for justice in policy or contexts outside of the US. Focusing on these important nodes would surely lead to important insights in these areas, but risks missing key, emerging, or surprising social issues. For example, rather than focusing on land as a starting point, it is useful to begin by thinking more broadly about distributive justice issues in relation to multiple resources, as we discuss in our analysis below.

Moreover, in talking about "doing" food justice, these approaches beg the question about the complementary process of what it means to "say" justice. As Fairclough (2010) reminds us, discourse is about how questions of what is possible to say and think affect what is "do-able." In this respect, we propose an accompanying process to the above examples that targets these questions, specifically in the policy realm.

In this light, we stepped back from examples of food justice in localized practices (e.g., US) to identify fundamental social justice principles that lay the theoretical groundwork for food justice. Reading through the literature, we identified two repeating themes in food justice definitions:

(1) "distributive" justice (Horst, 2017; MoraguesFaus, 2017); sometimes referred to in terms of “access" (Bradley \& Herrera, 2016; Longo, 2016); and (2) procedural justice (Horst, 2017; MoraguesFaus, 2017), variously referred to as "ownership and governance” (Bradley \& Herrera, 2016) or "community involve[ment] in the organization and structure of the food system" (Longo, 2016). In other words, these two dimensions of social justice frame a critique not just in terms of what is distributed but for whom and by whom the benefits and burdens of the food system are mobilized. We begin by offering a critique of the policy documents on these two dimensions of social justice in the Results section before presenting, in the following section, an elaborated framework "reading for social justice" that is specifically tailored to future policy analyses.

\section{Methodology}

Echoing Gibson-Graham's (2006) approach to "reading for difference" and "reading for absences," we have read our selected texts with the goal of "uncovering what is possible but obscured from view" and excavating "what has been actively suppressed or excluded" (pp. xxxi-xxxii). We use critical discourse analysis (CDA), a systematic approach to the analysis of language. We used this approach as it offers two main advantages: first, its ability to analyze the role of discourse in setting the boundaries of current and future possibilities; and, second, its attention to issues of social justice. Regarding the first, as Chiapello and Fairclough (2002) remind us, "discourse is not a closed or rigid system, but rather an open system, which is put at risk by what happens in actual interactions" (p. 194). We examine policy discourses in the "Brexit moment," a moment in which established and normalized practices can be surfaced and critiqued and alternatives can be proposed. Bearing in mind that food justice is a framework that has emerged from the grassroots, our objective was to analyze these (largely mainstream) texts on food and policy in order to understand the extent to which they aligned with issues of social justice.

Secondly, CDA is not a disinterested analysis; it is invested in "normative" discursive production, meaning that it is invested in explaining, as Fairclough and Fairclough (2012) put it, "why and how existing social realities endure despite their damaging effects" (p. 3) and (by implication) how to change them. This approach resonated with our specific objective of "reading for social justice." CDA can "help to facilitate learning through 
critical questioning, and thereby help open up the horizon-constituting potential of deliberation for producing alternative imaginaries and strategies" (Fairclough \& Fairclough, 2012, p. 23). Policymaking should, in other words, be approached as an opportunity for transformative learning (Anderson, Maughan, \& Pimbert, 2018). For this reason, we conclude with our five-point framework (Figure 1), which is specifically intended to inform and strengthen transformative policy making and analysis.

We conducted a systematic search for texts that were written after June 23, 2016 - the date of the UK referendum to leave the European Union-and up until November 2017. ${ }^{2}$ On an initial search, we found 25 documents. We chose to analyze only documents published by civil society organizations and government, which a) spoke directly to post-Brexit policy on food and farming and b) that gave recommendations for policy changes. From the initial set of 25 documents, we eliminated five that did not fit these criteria. We started by reading each text once through, discussing general patterns, then entering all documents into NVivo Qualitative Data Analysis software. We then collectively conducted a basic content analysis, identifying (a) what they sought to distribute and (b) whom they envisaged benefitting and participating (i.e., distributive and procedural justice). We then discussed and agreed on an initial coding structure. The remaining documents were then coded by the lead author and the emergent analysis developed iteratively in discussion between co-authors. The application of codes was subsequently reviewed by all co-authors, adjusted accordingly, and a final coding structure agreed upon.

During this coding process, our initial categories of distributive and procedural justice were modified; for example, under distributive justice, we settled on four subcategories of resources and advantages that the documents dealt with: land, food, public goods, and labor. This structure provides the form of our results and analysis and is presented in the following sections.

\section{Results}

\section{Characterizing the Documents and their Commissioning Organizations}

To begin our analysis, we asked some basic questions to help situate the documents within the overall policy landscape: What are the organizations behind these documents? What do they stand for? And what do they aim to achieve through their documents?

The commissioning organizations can be char-

\section{Figure 1. A Framework to Support a Process of "Reading for Social Justice" in Order to Evaluate Both the Content of Policies and the Processes through which Policies are Discussed, Formulated, and Decided Upon}

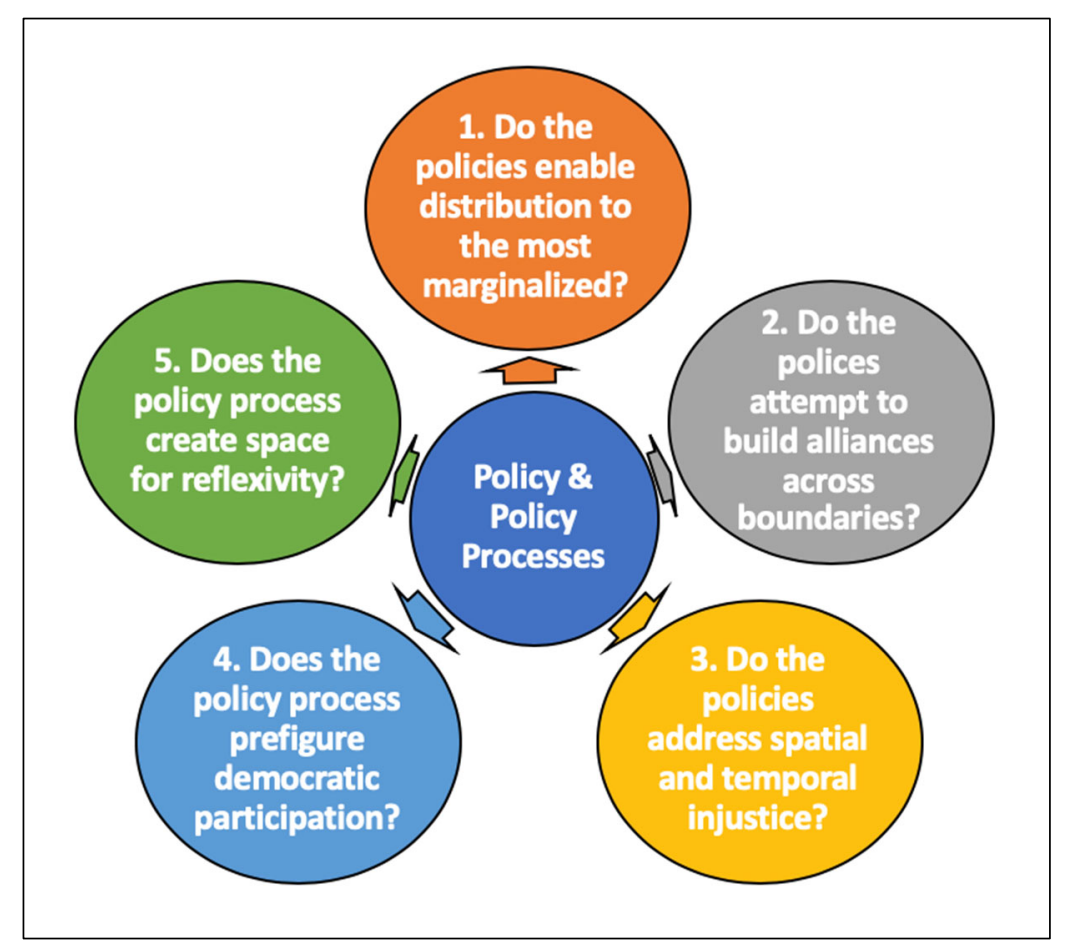

${ }^{2}$ Given the unforeseen length of the Brexit process, we return in the section "A Framework for Reading for Social Justice in Policy Discourse" to resituate our documents in light of subsequent Brexit-related events. 
acterized as falling into one of three categories (Table 1). Twelve organizations were nongovernmental organizations (NGOs), including charities, think tanks, and campaigning coalitions. Some of these are well known in UK food and farming debates; for example, Compassion in World Farming,

Table 1. Characterization of the 20 Documents, Their Authors, Organization Type, and Principal Aims

\begin{tabular}{|c|c|c|c|}
\hline Author (abbrev.) & Title & Type & Words \\
\hline \multicolumn{4}{|c|}{ Nongovernmental Organizations } \\
\hline $\begin{array}{l}\text { Centre for Policy Studies } \\
\text { (CPS) }\end{array}$ & $\begin{array}{l}\text { Pointmaker: Brexit, Agriculture and } \\
\text { Agricultural Policy }\end{array}$ & Free-market policy think tank & 9,651 \\
\hline $\begin{array}{l}\text { Compassion in World Farming } \\
\text { (CIWF) }\end{array}$ & $\begin{array}{l}\text { Sowing Fresh Seeds: Food, Farming, } \\
\text { and Animal Welfare Post Brexit }\end{array}$ & $\begin{array}{l}\text { Campaigning and lobbying charity (animal } \\
\text { welfare) }\end{array}$ & 9,551 \\
\hline Countryside Alliance & $\begin{array}{l}\text { Brexit Policy Document: Sustaining a } \\
\text { Living and Working Countryside } \\
\text { Outside of the European Union }\end{array}$ & $\begin{array}{l}\text { Campaigning and lobbying charity (rural issues, } \\
\text { hunting, farming, etc.) }\end{array}$ & 8,851 \\
\hline Eating Better & $\begin{array}{l}\text { Beyond the CAP: Policies to Support } \\
\text { Better UK Meat and Dairy Production } \\
\text { Post-Brexit }\end{array}$ & $\begin{array}{l}\text { Campaigning and lobbying coalition (healthy } \\
\text { and sustainable food) }\end{array}$ & 7,107 \\
\hline GM Freeze & GM Freeze Briefing-Brexit and GM & $\begin{array}{l}\text { Campaigning and lobbying group (genetic } \\
\text { modification) }\end{array}$ & 1,186 \\
\hline National Trust & The Future of Our Countryside & Conservation charity & 1,195 \\
\hline $\begin{array}{l}\text { New Economics Foundation } \\
\text { (NEF)/Global Justice Now }\end{array}$ & $\begin{array}{l}\text { Agricultural Subsidies in the UK After } \\
\text { Brexit: A Progressive Solution }\end{array}$ & $\begin{array}{l}\text { Left-wing think tank (NEF); Campaign group on } \\
\text { Global South development (Global Justice Now) }\end{array}$ & 18,396 \\
\hline A People's Food Policy (PFP) & $\begin{array}{l}\text { A People's Food Policy: Transforming } \\
\text { our Food System }\end{array}$ & $\begin{array}{l}\text { Coalition of civil society campaigning } \\
\text { organizations }\end{array}$ & 44,373 \\
\hline Policy Exchange & $\begin{array}{l}\text { Farming Tomorrow: British } \\
\text { Agriculture After Brexit }\end{array}$ & Center-right think tank & 27,022 \\
\hline Soil Association & $\begin{array}{l}\text { The Future of British Farming Outside } \\
\text { the EU }\end{array}$ & $\begin{array}{l}\text { Campaigning charity (food and farming)/ } \\
\text { certification body (organics) }\end{array}$ & 18,068 \\
\hline Sustain & Beyond 2020: New Farm Policy & Sustainable food charity/campaigning & 3,975 \\
\hline $\begin{array}{l}\text { UK } 2020 \text { (authored by } \\
\text { Paterson) }\end{array}$ & UK Agricultural Policy Post-Brexit & Center-right think tank & 7,324 \\
\hline \multicolumn{4}{|c|}{ Unions and membership organizations from the agri-food sector } \\
\hline Fairlie/LWA/Greens & $\begin{array}{l}\text { Farming Policy After Brexit: A Report } \\
\text { for The Greens }\end{array}$ & $\begin{array}{l}\text { Campaigner/member organization for small- } \\
\text { scale producers and family farmers }\end{array}$ & 27,559 \\
\hline $\begin{array}{l}\text { Food and Drink Federation } \\
\text { (FDF) }\end{array}$ & FDF Manifesto 2017 & $\begin{array}{l}\text { Members organization/industry representation } \\
\text { (UK food and drink manufacturers) }\end{array}$ & 2,852 \\
\hline $\begin{array}{l}\text { The Landworkers' Alliance } \\
\text { (LWA) }\end{array}$ & $\begin{array}{l}\text { Making Food Sovereignty a Reality: } \\
\text { Recommendations for Post-Brexit } \\
\text { Agricultural Policy }\end{array}$ & $\begin{array}{l}\text { Member organization for small-scale producers } \\
\text { and family farmers }\end{array}$ & 9,382 \\
\hline $\begin{array}{l}\text { National Farmers' Union } \\
\text { (NFU) }\end{array}$ & $\begin{array}{l}\text { Policy Statement: Next Steps for } \\
\text { Agricultural Policy_A New Deal for } \\
\text { Society }\end{array}$ & $\begin{array}{l}\text { Member organization/industry association for } \\
\text { farmers in England and Wales }\end{array}$ & 1,722 \\
\hline $\begin{array}{l}\text { Tenant Farmers Association } \\
\text { (TFA) }\end{array}$ & A Post EU Farming Policy for Britain & $\begin{array}{l}\text { Member organization/industry association for } \\
\text { tenant farmers in England }\end{array}$ & 1,596 \\
\hline Ulster Farmers' Union (UFU) & $\begin{array}{l}\text { UFU Discussion Document Brexit: } \\
\text { Options for a New Domestic } \\
\text { Agricultural Policy }\end{array}$ & $\begin{array}{l}\text { Member organization/industry association for } \\
\text { farmers in Northern Ireland }\end{array}$ & 1,652 \\
\hline \multicolumn{4}{|l|}{ Governmental Organizations } \\
\hline $\begin{array}{l}\text { All-Party Parliamentary Group } \\
\text { on Agroecology (APPGA) } \\
\text { (authored by Mansell) }\end{array}$ & $\begin{array}{l}\text { Inquiry into Trade Post-Brexit Briefing } \\
\text { Paper }\end{array}$ & $\begin{array}{l}\text { Informal, cross-party, interest group for MPs } \\
\text { and Peers }\end{array}$ & 4,913 \\
\hline $\begin{array}{l}\text { House of Lords-EU } \\
\text { Committee (HoL) }\end{array}$ & Brexit: Agriculture & Government select committee (House of Lords) & 41,721 \\
\hline
\end{tabular}


The National Trust, and The Countryside Alliance. These organizations have large memberships, have existed for many decades, and are influential in terms of farming and land use in Britain. The $\mathrm{Na}$ tional Trust, for example, is the nation's largest farm owner, with more than 250,000 hectares of land and more than 1,500 tenant farmers (National Trust, n.d.). Others are less well known; for example, A People's Food Policy, GM Freeze, and UK 2020 (authored by Paterson) — these are comparatively new, and what they stand for is perhaps less well understood by the general public. The second group (six organizations) is made up of unions and membership organizations from the agri-food sector. In this group only two are particularly well known at a national level: the National Farmers Union (NFU), with over 55,000 members, and the Food and Drink Federation (FDF), representing over 300 companies. Others are, again, much smaller and operate with small memberships and financial turnovers. The final group (two organizations) is composed of governmental bodies, one being a branch of government (The House of Lords) and the other an informal cross-party parliamentary group (the All-Party Parliamentary Group on Agroecology [APPGA]).

It is clear that the different publications are intended for a range of audiences. For example, the reports by the House of Lords (HoL), the Policy Exchange (a leading UK think tank), and Simon Fairlie (a well-known ecologist and author) are aimed at specialist audiences. Reports by civil society organizations such as the Soil Association, Eating Better, and Sustain are aimed at a wider public, and use accessible graphic design and plain language to break down complex food and farming policy into manageable sections.

\section{Distributive Justice}

All of the documents made claims for how resources should be reallocated, post-Brexit. The prospect of leaving the EU opened up a renegotiation of the ways in which public funds are distributed, and also for the application of regulatory and legislative instruments with redistributive intent. As such, the proposed changes could have important implications in terms of "distributive" justice, i.e., the form of social justice that concerns the "distribution of material or economic advantages" (Olsaretti, 2018) throughout society, as well as the conditions under which individuals can access such advantages. We present the following sections using the four main categories of resources and advantages that the documents dealt with: land, food, public goods, and labor (Table 2).

\section{Land}

Land concentration can be considered one of the greatest injustices underlying the UK's food system, reflecting a history of land enclosure and unequal power relations going back over 1000 years (Shrubsole, 2019). The current pattern of land ownership not only presents practical impediments to shifts towards sustainability but represents the "most neglected issue in British politics" (Monbiot et al., 2019). While land per se was a prominent concern of the majority of documents (17 of 20), the most common approach to land policy was

Table 2. Summary of Documents in Terms of the Various Categories of "Distributive Justice"

\begin{tabular}{lll}
\hline Category & Subcategory; no. of documents; commissioning organization \\
\hline \multirow{2}{*}{ Land } & $\begin{array}{l}\text { Land use (11): APPGA; CIWF; Countryside Alliance; CPS; Eating Better; HoL; National } \\
\text { Trust; Policy Exchange; Soil Association; UFU; UK 2020 }\end{array}$ \\
\cline { 2 - 2 } & Land ownership/access (6): Fairlie; LWA; NEF; PFP; Sustain; TFA \\
\hline Labor & Access to labor (9): APPGA; CPS; FDF; HoL; NFU; Policy Exchange; TFA; UFU; UK 2020 \\
\cline { 2 - 2 } & Labor conditions (7): Fairlie; FDF; HoL; LWA; PFP; NEF; Sustain \\
\hline Public goods and/or & $\begin{array}{l}\text { Public goods (13): HoL; UK 2020; Policy Exchange; Sustain; National Trust; Soil } \\
\text { access to nature }\end{array}$ & Association; CIWF; LWA; PFP; Countryside Alliance; APPGA; NEF; TFA \\
\hline Natural capital (6): CPS; HoL; NFU; Policy Exchange; UFU; UK 2020 \\
\hline Food access & CIWF; Eating Better; Fairlie; FDF; LWA; Soil Association; Sustain; UK 2020 \\
\hline
\end{tabular}


land use (addressed by 11 of 20 documents). This included suggested changes in the way land is managed, what is grown on it, and what measures might be introduced to incentivize less environmentally damaging farming practices. Organizations like the Soil Association, Policy Exchange, and APPGA, for example, call for some variation on a comprehensive land management scheme. These schemes aim to deliver "a cost-effective approach to mitigating carbon emissions" (Policy Exchange, 2017, p. 9), but also as a means to "[improve] production efficiency" (UFU, 2017, p. 4). UK 2020 (2017) is perhaps the most strident in its declaration that "the first priority in growing the rural economy must be to increase food production" (p. 4).

Just over a quarter of the documents (six out of 20) addressed the issue of land ownership, control, and access. Land ownership in the UK is highly concentrated. While estimates vary, some suggest less than $1 \%$ of the population (i.e., some 25,000 individuals) own more than half the land (Shrubsole, 2019). A clear account of who actually owns the land in the UK is further obstructed by the lack of a publicly accessible land registry (Monbiot et al., 2019). Such problems might reasonably be expected to be a priority for any organization interested in the future of the UK food system. However, problems associated with land tenure and land concentration are hardly mentioned across the documents, and proposals for land reform are dealt with by only three of the 20 .

Where land access was addressed, it was by proposing measures to support new entrants who are locked out of farming because of inadequate access to land, by changing the subsidy system to end public direct payments to large landowners (TFA; NEF), or by combining the two approaches, as is the case with LWA, Sustain, and PFP. In one other instance, land access issues were mentioned, but only in regard to identifying "land that can be used for housing or commercial development, sharing the planning uplift with the original farmer" (Policy Exchange, 2017, p. 45). In his report for the Green Party, Fairlie (2017) takes a particularly strong line on the injustices in land ownership and the need for land reform, invoking the "right of people to engage with the natural world through farming and similar land-based activities" (p. 15). The PFP (2017) offers a raft of policies, even including those which draw on "the government's extraterritorial human rights obligations and in order to address land grabbing and human rights violations overseas" (p. 53). Rightsbased claims regarding access to land are missing from the rest of the documents, and around three quarters (16 out of 20 ) do not deal with land access at all. None of the documents specifically mentioned the issues of access to land for minority groups, including women, or ethnic minorities, which has been a lynchpin of food justice discourse in the North American context-and is certainly an issue in the UK (though there is very little research on this topic).

The documents that consider changes to who owns the land are a small and isolated minority. Despite strong evidence of the role of land concentration in limiting land-use changes (Zondag, de Lauwere, Sloot, \& Pauer, 2015), the absence of land reform in these documents is a failure to address one of the most fundamental food justice issues. The Countryside Alliance (2017), for example, pushes the importance of "traditional land management in creating and maintaining some of our most iconic rural landscapes" (p. 17), but does not cite land tenure reform as a means to achieving this. This omission is striking, given the impact of large-scale industrialization in undermining traditional farming practices. In short, silences around land reform demonstrate the "unsayable" nature of land reform in the mainstream policy landscape.

\section{Labor}

In the UK, labor has particular relevance within the food system and to issues of social justice. Around 392,000 people are employed in food and drink manufacturing, and almost a third of these are EU migrants; food and drink is the country's largest manufacturing sector, yet many of the workers are employed on low-wages and/or precarious contracts (Heasman \& Morley, 2017). It is estimated that $48 \%$ of the workforce in the food industry is classed as low paid (twice as much as for the economy as a whole) (Fabian Society, 2015).

Labor was a key focus across the documents, featuring in 16 of the 20 reports. The most com- 
mon way it was discussed, however, was in terms of "access" to labor, particularly "unskilled" or "seasonal labor" (CPS; HoL; UK 2020; APPGA; NFU). The NFU (2017), for example, advises that the UK government "ensures the industry's labour needs are met" (p. 1). Elsewhere, the discussion taps into fears, as APPGA (Mansell, 2017) put it, that a "failure to secure this labour-source could add substantially to the cost of producing" (p. 2). In this sense, the dominant narrative across the documents reflected labor as a commodity.

A minority of documents (seven out of 20) focus on the interests of workers, such as conditions and pay. Two of these, however, pertained to less precarious "skilled labor" such as veterinarians or "sector-specific" tasks such as abattoir workers (FDF and HoL). The issue of non-agricultural labor in the food system (i.e., in food manufacturing and catering) was only mentioned in two of the documents (PFP and FDF). Despite recent increases in the prominence of migration issues, both in food systems and outside them (IOM, 2018), the issue of gang-labor exploitation (especially of migrants) was notably muted (or even absent) in all but seven of the documents. Where it is discussed, it is again routinely from the perspective of employers: "the pig industry," the HoL report (2017) tells us, "would struggle to survive without migrant labour" (p. 68).

Despite the particularly stark gender pay gap in agriculture and rural areas (Farmer's Weekly, 2015; Recanati, Maughan, Pedrotti, Dembska, \& Antonelli, 2018), women are mentioned in only one document (PFP). In addition, only two reports (Sustain and PFP), make any mention of reviving the Agricultural Wages Board-one of the most cited mechanisms for tightening labor regulations for the most precarious in the food system (Devlin, 2016; Sustain, 2018). Similarly, Sustain (2017), which also calls for the "Living Wage" for "farmworkers," calls for "a new agricultural worker collective bargaining body," noting its capacity to "protect workers from abuse" (p. 6).

Two main issues are of relevance here. Firstly, the tendency to frame labor as a "resource" rather than a rights issue. When labor is considered only as a resource, the human impacts of increased casualization, declining pay, and poor working condi- tions are disregarded. Compare the NFU's emphasis on "the industry's labour needs"-which talks of labor in the same way it might talk about electricity supply-with the LWA's proposal to address migrant labor issues. The LWA frames this in terms of "welfare," but also envisages beneficiaries beyond their membership (e.g., producers in the Global South). The distinction is subtle but important for building an argument and a broadbased movement to improve labor conditions.

The second issue is the failure to draw links between conditions relating to agricultural labor and food labor more generally. Only one document (PFP) makes any explicit reference to workers in the foodservice industry. The PFP gives substantial consideration to food workers, grouping them with "vulnerable workers and migrant workers" across the food system. The connection between agricultural policy and food policy is a fraught one; however, calls are increasing to link the two (Candel \& Pereira, 2017; International Panel of Experts on Sustainable Food Systems [IPES-Food], 2019). To ignore these commonalities is to miss the interdependence of cheap food (at great environmental cost) and cheap labor (at great human cost) (Patel \& Moore, 2017). Moreover, failure to discuss these interdependencies is strategically limiting: if it is not possible to talk about the things that are crucial in the pursuit of just sustainability-building crosssectoral alliances, achieving policy coherence, and creating more participatory forms of governancethen what is chance of doing them? (For more on this see the Framework for Reading for Social Justice in Policy Discourse section, below).

\section{"Public goods" or access and use of nature and ecosystem services}

Agro-ecosystems offer innumerable benefits; however, access to them is highly uneven throughout society. In the documents, access to nature and ecosystem services was a prominent concern (19 out of 20 documents), though it was most often framed from the perspective of the provision of "public goods" (discussed in 13 of 20 documents). As one organization defined it, public goods are "product[s] that one individual can consume without reducing its availability to another individual, and from which no one is excluded" (Sustain, 
2017 , p. 2). The notion of public goods has an inherent food justice dimension for two main reasons: firstly, because the goods arising from food systems (such as sustainable, healthy, and nutritious food) are accessed in uneven ways by differently positioned actors, but also because defining and setting public goods is a matter of public discourse. In other words, who gets to decide what these goods are, how they are delivered, and who benefits, depends on who has the power to influence the debate.

Many documents made general claims for the need to ensure that the agricultural system (and private landowners) is supported to provide public goods, but there was little emphasis on unequal access between different sub-groups within "the public." Further, exactly how the natural environment is valued and how it fits into broader economic and social logics varies extensively in the documents. As one report put it, we need

'payments for goods that go beyond food production-for the wildflowers, bees and butterflies that we love, for the farmland birds, now threatened, for the water meadows and meandering rivers that will help prevent the flooding of our towns, and for the rebuilding of the fertility and health of the soils on which both nature and production depend.' (National Trust, 2016, para. 7)

Here the emphasis is on the aspects that often escape valuation in agricultural policy, but that nonetheless are of great value. Broadly speaking, such interventions were reflective of an overall dissatisfaction with previous iterations of the CAP and its distorting effects (on both markets and natural environments). For example, Owen Patterson (former Secretary of State for Environment, Food and Rural Affairs), despite championing economic competitiveness, still felt the need to point out in the UK 2020 report that while some can "compete with global markets, there are others [for] which food production cannot be the sole means of generating income. These areas will particularly benefit from a system to reward and sustain farmers for their environmental and conservation work" (Paterson, 2017, p. 16).
A distinction emerged in the documents between "market-oriented" and "rights-based" conceptions of how and why public goods should be provisioned. Consider, for example, the framing evident in the excerpt from National Trust's document cited above. This formulation frames nature not as a commodity or factor of production, but as "the things we love" that should be paid for with public money-quite distinct from, for example, the Policy Exchange's (2017) vision of "creating a competitive market for the provision of ecosystem services" (p. 9) or the NFU's (2017) desire to ensure farm income by "recognis[ing] and reward[ing] the environmental goods that farmers deliver" (p. 1).

It is the House of Lords (2017) report, though, that provides the clearest example of a marketbased approach. This report suggests that the high standards integral to the provisioning of public goods "were crucial to the British brand" and on this basis recommends that "the Government should, therefore, maintain the current standards to enable the export of UK food and farming products" (p. 43). Such an approach, as numerous commentators have suggested (McCarthy \& Prudham, 2004), can easily obscure the inherent nonmonetary value of public (and common) goods, such as public access to nature and benefits for future generations.

The wide range of possible public goods may appear odd; however, as already stated, it is a wellknown feature of public goods discourse (Touffut, 2006). Public goods may function here to artificially conceal the extent of disagreement among key agri-food stakeholders. For example, there is a disparity between market liberals like UK 2020 and Policy Exchange, centrist NGOs like the Soil Association and CIWF, and food sovereignty advocates like LWA and PFP. Yet all of these organizations appear to recognize the term, positioning their more specific (and contrasting) policies within it. This is of obvious benefit to the government who wishes to appease otherwise divergent interests. Indeed, they have actively promoted the term - for example, in their "Health and Harmony" Green Paper (Defra, 2018a), in which they used the term to mean anything from "climate change mitigation" to "improved produc- 
tivity and competitiveness." The regulatory power of forthcoming legislation will likely be weakened by this vagueness.

\section{"Food access"}

The United Nations" Food and Agriculture Organization (FAO, 2006) defines food access as "access by individuals to adequate resources ... for acquiring appropriate foods for a nutritious diet" (p. 1). This concept normally puts considerable emphasis on the structural constraints (such as poverty) that modulate the ability of individuals and groups to access food, rather than its physical availability. While such a conception glosses over important factors such as health and nutrition, food access is strongly connected to food justice, which, as we have seen, highlights the often-invisible constraints that keep certain individuals and groups in positions of deprivation.

Food access was mentioned by eight out of 20 of the reports; however, very few actually address the issue in great detail. The documents that address food access offer a wide range of options, including taxation to fund the subsidy of "nutritious" food (EB; CIWF; SF), right to food legislation (PFP; LWA), public awareness-raising about "healthy eating on a low income" (CIWF, 2017, p. 1), public procurement (Soil Association; Sustain), subsidies and loans for horticultural producers (Sustain), and passing on savings to consumers by leaving the Customs Union (Paterson, 2017).

Also included in this analysis are those documents that talk about "poverty," which is also understood to denote structural constraints on the ability of individuals and groups to feed themselves. Accordingly, the issue is often talked about as part of a wider strategy. For example, the Soil Association (2017) talks about "a joined up approach ... taking account of public health, food poverty and international development" (p. 8). The LWA (2017) also advocates for government-implemented schemes such as "food stamps" and subsidies on local produce as a way to "alleviate food poverty" (p. 6). That said, food poverty is also mentioned in some documents but not as part of any particular strategy (PE; CIWF; NEF). Finally, there were only two documents (NEF and Fairlie) that considered the implications of food and farm- ing policy for food security (as well as ecosystems, etc.) elsewhere in the world. The NEF (2017) argues that "the most important principle for a new UK subsidy system is to do no harm to producers in the global south" citing the role the UK plays in feeding the "world's population" (p. 4).

Only two documents (PFP; Sustain) mention food banks, and only a handful more give any indication that food access and food poverty are pertinent issues for discussion. One fairly straightforward reason for this discrepancy might be that most of the documents did not consider it to be within their scope. The vast majority have a principal focus on agriculture, and in the European context, policy debates have been dominated by the issue of agricultural subsidies. As the NEF (2017) put it, food access is "not easily influenced through the policy tools of agricultural subsidies" (p. 10), and as a result, they chose not to discuss it. The $\mathrm{NEF}$ is candid about its rationale; elsewhere, no discussion is given at all. Whatever these reasons, the practical result is the presentation of food access and those who eat food as a fringe concern, separated from issues of agriculture and production, an idea that is further entrenched by those who remain silent.

Even when food access is discussed as a policy issue, considerable divergence can be observed in ways that reflect different political positions and imaginaries of social change. On the one hand, documents advocating for a "right to food" approach are based on an "official recognition that food is not a commodity but a basic human right" (LWA, 2017, p. 17; also PFP), positioning the state as the ultimate guarantor. Other proposals seek to improve the food environment through various public health initiatives. Eating Better (2017), for example, calls for the use of "fiscal measures such as introducing VAT or other tax on some types of livestock products" to "subsidise healthier foods." Sometimes these proposals were fairly vague-e.g., calls for the government to "create a new food culture" (CIWF, 2017, p. 6)—though sometimes (again especially with PFP) they were attached to concrete proposals to implement laws and create institutions (or strengthen existing ones) to help build a healthy food environment. These approaches were unified by their targeting of 
underlying structural causes.

In contrast were those documents that envisaged the operation of the market as the best method for delivering increased access. For example, the FDF (2017) suggests that improvements to food access will be secured by growing "a more competitive and productive supply base, delivering resource efficiency, quality and traceability from farm to fork" (p. 6). This example points out the way-much like with "public goods"- that social problems around food can easily be reframed as market issues. Other organizations do this, toothe CPS (2017), for example, calls for an arrangement "which meets consumers' needs in terms of the availability of nutritious food at reasonable prices" (p. 14), echoing a long-standing emphasis on a cheap-food policy for all as the best means to address food insecurity. Framing the issue in exclusively consumer terms can make invisible certain forms of need that cannot be met by market mechanisms (e.g., extreme poverty) nor solved through "reasonable pricing." This is in contrast to more active formulations of political subjects such as "citizens," or even "eaters" (in the case of Eating Better), which are compatible with the human right to adequate and nutritious food.

\section{Procedural Justice}

As food justice advocates often point out, how people are engaged in decision-making has an important bearing on what changes are actually made, and their capacity to benefit those most in need (e.g., Horst, 2017; Moragues-Faus, 2017). As such, we were interested to find out to what extent "procedural justice" was reflected in these documents by asking both who was involved and how.

\section{Appeals in the policy documents to reforms in governance}

Less than half (nine out of the 20 documents) discuss issues of governance and decision-making processes. Those that do, make clear calls for increased public participation; for example, the $\mathrm{Na}$ tional Trust (2016) calls for "the public in the debate, along with organizations who have experience and insights to share"' (para. 17); similarly, Fairlie (2017) suggests establishing "a forum of like-minded organizations" (p. 40) to help advise the government, and Sustain (2017) points out that "local decision making ... needs urgent but careful work" (p. 4). Market solutions are represented too-Policy Exchange (2017), for example, calls for the government to "work with local areas" to develop "industrial strategies" (p. 54). One special case is the LWA. While basing their report around food sovereignty —one pillar of which is to "put control locally" (Global Justice Now, n.d.) - they do not actually deal directly with the issue of decision-making, and are mentioned here only because of the implicit connections between the idea of food sovereignty and democratizing food systems.

Only a small fraction of the documents go into any detail on the issue. The PFP (2017), for example, outlined a democratic deficit as a fundamental problem underpinning larger problems in the food system and then suggested a series of policies to "establish democratic structures and mechanism for public participation in food policy-making and governance" (p. 28). This proposal included establishing statutory "food partnerships" in each regional, metropolitan, and local authority that would feed into a national people's food policy councileach of which would involve broad and diverse civil society participation. The only other document to provide any detail was by the NEF (2017), which recommended establishing a "participatory representative body with a public interest mandate" modeled after the "Brazilian national council, CONSEA" (p. 24).

\section{The extent of participation in the production of policy positions}

In addition to proposals for procedural justice, we were also interested in examining to what extent the documents themselves were produced in ways that reflect participatory and procedural justice. There was very little evidence of explicitly democratic procedures being built into the drafting of the documents themselves. In fact, there was a preponderance of single-author, or elite group-authored documents: authorship statements like "Dame Helen set out six principles that any new system must deliver for the public" (National Trust, 2016, "The future of farming," para. 1) and "words by James Somerville-Meikle" (Countryside Alliance, 2017, p. 22) were common. Even NEF, while offering some of the more stridently demo- 
cratic policy proposals, used elite consultation as their central methodology. This methodology, they state, "allowed us to identify the important concepts and ideas already being debated, and those that needed to be brought into the debate" (2017, p. 9).

In a large number of cases, no description of the drafting methodology was given at all. For example, unions and members organizations routinely run consultative processes with their members (we know this happened in the case of LWA), but most make no mention of it in the documents themselves (UFU, TFA, NFU, FDA). In one case, the House of Lords report, some degree of participation was built into the public hearing format. The report itself does not provide a great amount of detail on this or what opportunities (if any) there were for public participation. However, it does signal to an impressive repository of individual testimonies provided by the hearing's expert witnesses.

Beyond this, there were only two instances of expressly participatory processes being used in the document drafting methodology. The first is the Eating Better (2017) report, which informs us its outcomes were "developed in collaboration with ... over 50 civil society organizations working to build consensus and develop collaborative practical approaches" (p. 2) for food system transformation. This is in marked contrast to the detail given — and very deliberately emphasized — by the authors of the PFP. The document includes a wide range of policies designed to address public participation in food and farming policy-making directly -for example, the "statutory food partnerships" already mentioned, as well as "a National People's Food Policy Council” (2017, p. 29). Importantly, the document also describes how such principles were built into the drafting of the document itself, including "consultations, workshops and a survey" with input "from over 150 organizations [... from] across the food system and civil society" (2017, p. 21). The PFP also expressed an intention to expand participation by including "those who haven't supported this work to find out where the differences in our positions and ideas are and reconcile them" (2017, p. 94).

Elsewhere, the lack of detail on either the topic of democratic governance or participatory policy- making is perhaps one of the biggest ironies of the Brexit process, a process ostensibly intended to reclaim political sovereignty: a "once-in-a-generation opportunity" (Defra, 2018b) to make a more democratic and prosperous nation. Shortcomings such as this illustrate the extent to which the Brexit discourse has been seriously affected by the fear of economic shock and political division. Moreover, since these documents were composed relatively early on in the Brexit process, they also demonstrate that such constrained thinking has been active from the outset. Despite some standout documents (such as PFP, LWA, and Sustain), on the whole, the organizations represented in this study played it safe, in effect protecting vested interests rather than advancing a broader vision of ecological and social justice.

The limited nature of the proposals in these documents represents a missed opportunity to use the "Brexit moment" to redress shortfalls directly in democratic governance. This is in tension with calls for more substantial civic participation in food system governance. The National Trust (2016) document exemplified this contradiction, despite being solely based on the thoughts of a member of the House of Lords (see above), as it still advised "ministers to now consult widely on the way we fund farming in a post-Brexit world and involve the public in the debate, along with organizations who have experience and insights to share."

Stepping back and looking at who is reflected in the documents, it is notable that there are no organizations that explicitly include representation of marginalized and vulnerable groups (BEM, migrant workers, women, etc.), meaning that the discourse is being (re)produced by those who already benefit disproportionately from it. This clearly has implications regarding the extent to which the discursive arena itself, and the production and negotiation of discourse on food and farming policy, can reflect diverse interests and needs. This shortfall is worrying - without a clear intention to build participation of diverse groups (especially marginalized ones) back into the food system, the social divisions which gave rise to Brexit in the first place may even widen. In the following section, we set out a five-part framework for "reading for social justice." Presented as a series of questions, this 
framework is designed to help advocates, policymakers, and organizers to reflexively scrutinize policy positions and processes in terms of often-hidden "distributive" and "procedural" justice issues.

\section{A Framework for Reading for Social Justice in Policy Discourse}

While the empirical research of this study focused on publications produced in a discrete period in the immediate wake of the Brexit referendum (June 2016 to November 2017), much has unfolded in the intervening months, not least a landslide general election victory for the Conservative Party and final confirmation that Brexit will happen on the $31^{\text {st }}$ January 2020. In addition, numerous parliamentary bills have been drafted and debated; the agriculture bill, for example, triumphantly announced the introduction of a "public goods" framework, but also saw a failed attempt to introduce an "agroecology amendment." Similarly, the passage of the trade bill has created controversy around the lowering of labor and food quality standards threatened by a USA-UK free trade agreement. Public concern was especially enflamed when government papers were leaked, suggesting such a deal would "severely limit" Britain's ability to negotiate an equivalent agreement with the EU (Pickard, 2019).

Outside parliament, the conversation has also continued. Of particular note, was the visit by the United Nations (UN) Special Rapporteur on extreme poverty, Philip Alston, who described the role of government policies in the "systematic immiseration [economic impoverishment]" of a significant part of the UK population (BBC News, 2019). Numerous other significant discursive moments have occurred, such as the launch of the $\mathrm{Na}$ tional Food Policy consultation and the release of findings by the RSA special report on food and farming, which stressed, among other things, reorienting food systems for public benefit (RSA, 2019).

The majority of topics in the public debate have been around public health and food quality issues (e.g., concern over the possibility of chlorinated chicken being allowed in the UK) (Lawrence, 2019). In contrast, issues of lowering labor standards, entrenched food poverty, and other food justice concerns have received far less attention. Thus, the pattern we observed in our empirical analysis of the first wave of post-Brexit policy positions (in the 20 papers we analyzed) generally repeats itself in today's debates where social justice issues are muted or unsurfaced. While explicit attention to social justice was rarely considered on the surface of many of the documents we analyzed, the implications for social justice lurk in the shallow waters of the debates. Our approach to "reading for social justice" is designed to help to get below the surface and wade through the unarticulated, but multidimensional, depths of social justice issues.

To this end, we offer below a framework that discusses our findings to further develop our initial focus on distributive and participatory justice. This framework has evolved out of a combination of our analysis of sample policy documents and existing food justice literature; it is offered both for the ongoing context of Brexit policy-making, but also as a set of principles to deepen the analysis of policy production in general. As a political process of "deciding what to do," policy is a privileged site of discursive production that sets limits on both what we can say and what we can do. Criticism of policy must be conducted systematically and reflexively if we have any hope of shifting its horizon of possibility.

\section{Do the policies enable the distribution to (and participation of) the most marginalized?}

As we have seen, all engagements with Brexit have been to some extent about redistribution-whether it is about redistributing benefits to the general public or small farmers, or allocating public funds to farmers who are producing public goods. However, the engagements that most reflect a food justice perspective are those that have adopted a more critical and wide-ranging stance. In respect to the distributional issues discussed above, it is important to consider not just how small farmers can access land, but how the structurally disadvantaged, including, for example, women or black and ethnic minorities, can overcome the substantial and particular barriers they face. While many of the proposals appealed to a generalized and broad beneficiary "public" (e.g. "public goods," consumers, and the "economy," etc.), future policy analysis should strongly scrutinize any policy proposal with 
the question "for whom?." Proposals which set either vague or overly narrow targets, or, more importantly, that ignore or exclude marginalized and vulnerable stakeholders, should be identified and made familiar with ways in which to expand their horizon.

\section{Do the polices attempt to build alliances across boundaries?} The organizations in this study largely reflect middle-class and (often) agricultural interests, with not one organization or author explicitly committed to the interests of particular marginalized groups (beyond a focus on small farmers or landworkers). In this respect, the food justice perspective has frequently challenged food activists and organizations to consider and check their own self-interests, which are often from a privileged vantage point, through allyship, decentering their own power, enabling the leadership of marginalized constituencies, and centering their priorities and perspectives. As we have seen, it is the most vulnerable in society, often living in urban areas, who will be most affected by problems in the food system, such as food access and deteriorating labor conditions. Nevertheless, the policy proposals in these documents rarely addressed this, and may even represent a moment of consolidation of an urban-rural divide in food and farming policy. Building on the work of advocates of a "common food policy" (as well as some documents featured in this analysis (PFP, Sustain, Eating Better), we argue that future policy processes must attempt to bridge this divide, not only for the interests of the least well off, but because of the strategic alliances this could help forge.

\section{Do the policies address spatial and temporal injustices?} Very few of the documents considered interests, beneficiaries, and implications for food systems beyond national borders (including issues relating to migration). Moments of crises and change— such as Brexit-debated within a particular territory or country (e.g., national-level post-Brexit policy) can reinforce an inwards and protectionist posture that strengthens colonial relations and further shifts harm outside of national boundaries (e.g., shifting environmentally damaging production to the Global South while greening agriculture and im- proving economic conditions for farmers in the UK). Many of the worst social and economic injustices of the food system arise through the continued exploitative relationship between the Global North and the Global South.

These discourses were further bounded by their focus on the short term. The documents, their arguments, and their analyses are almost entirely timeless: ahistorical analyses with almost no consideration of the past. What seems clear is that deeper-seated social justice issues related to historic trauma, the legacy of slavery, uneven patterns of land ownership, the historical plight and struggles of farm and food workers, and the colonial underpinnings of the food system are completely absent. Whereas the past traumas of slavery, colonization, and indigenous dispossession are, to a greater extent, active in debates on food and farming in North America, these issues are hardly visible in the debates on food and farming policy in the UK.

\section{Does the policy process prefigure democratic participation?} The Brexit discourse was initiated in part around ideas of democracy and sovereignty. However, these debates have often appealed to extremely narrow concepts (as in the case of nationalism) or produced contradictory outcomes (i.e., instances where leaving the EU may result in even fewer chances to participate in processes that affect the $\mathrm{UK})$. The reasons for this are complex; however, we argue here that practices of regular political participation must be mainstreamed to avoid ambient political disaffection being captured by narrow populism. Democracy is difficult, and, like any skill, practice is essential to improve performance. Some documents did, in fact, use the Brexit moment to enact or prefigure democratic participation on a small scale by establishing broad consultative processes (e.g., Eating Better and PFP). The wider practice of this type of participation will provide skills and cultural norms that can help push back against the status quo of elite control over policy discourse and policy-making. This type of democratic practice must be locally determined. However, it may follow tried and tested formats of community-run farms and food policy councils, as well as more emergent forms, such as people's food policy processes, people's 
assemblies, citizen juries, and other deliberative processes.

Does the policy process create space for reflexive learning? Our final dimension of reading for justice is crosscutting. It concerns the idea of "reflexivity"-a practice of mindful awareness of one's own relative power within society. Looking at and continually critiquing one's own practices and politics is a fundamental but rare dimension of activism, sustainability, and policy-making. This principle arises as an obvious implication of the above-that much of "reading for social justice" will require a critique of oneself (and the organizations one is acting within). This will involve a process of learning and selftransformation by those who occupy these spaces and who are producing discourse as the basis for action towards food justice. Placing reflexivity in the context of transformative learning will also allow linkages with pre-figurative participatory democracy, which, as already stated, can be difficult to access or promote, especially for inexperienced participants. Constructing a deliberate intent to enact and signal policy-making as a gradual learning process, rather than a fixed and all-or-nothing endeavor, is essential. So defined, reflexivity will be critical to open up the horizon for, and the possibility of, the other four principles detailed above.

\section{Conclusion}

This paper provides the first analysis of the implications of food justice in policy discourse in the UK. The paper demonstrates the limited ability of the Brexit moment to generate policy advancements in the area of food justice. We have identified shortcomings in areas such as the framing of public goods, the consideration of food workers, and the opportunities for participation of marginalized groups. These limitations, it must be noted, are true of Brexit more generally, where an emergency logic is prevailing, displacing some of the purported objectives of political control and autonomy. With very few exceptions, the post-Brexit food policy discourse was shaped by a narrow conception of urgency - one bound by self-interest, dependent on elite knowledge, and involving negligible participation. The five-part framework we have offered in this paper provides an important tool for incorporating social justice into policy positions and lifting the priorities and voices of the marginalized in policy-making discourse.

These findings resonate with the literature on food justice that demonstrates the ways in which social justice gets side-lined (Alkon \& Norgaard, 2009; Cadieux \& Slocum, 2015; Moragues-Faus, 2017; Sbicca, 2018) or framed in a way that neglects structural causes of injustice. Using the work of Fairclough (2010), we have sought to describe this neglect in terms of the "unsayable." Though Fairclough describes public discourse as having the potential to open up "possible worlds," what we have instead seen is largely an inability to say or speak about certain injustices, leaving food justice effectively undoable.

Expecting agricultural policymakers and contributors to consider the urban poor, farmworkers, disabled people, or adopt a decolonial view might appear quixotic. However, the analysis presented in this article demonstrates how constrained the discursive horizons of agricultural policy-making are at present. Prompting these actors who already have a platform in the discursive arena to decenter their own perspectives and interests is one important part of a process that will help shift debates towards food justice. However, one of the most important limiting factors in these arenas is participation - the voices of those most negatively affected by dynamics in food systems (especially food workers, migrant labor, and the urban and rural poor-recognizing that these are not homogenous groups and that their experiences are differentiated through the intersections of race, class, gender, sexuality, age, ability, and more) are underrepresented in these processes. Few organizations in mainstream UK food and agricultural policy-making explicitly stand for such diverse groups or their needs, and until this is redressed, the possibilities for achieving any substantial version of food justice will remain unrealized.

Future research and policy could both focus on developing emerging tools of participatory policy-making processes capable of engaging with (and responding to) diverse experiences in society, such as citizens assemblies, citizen's observatories, and collaborative policy platforms like PFP (Anderson, 2017). Imagine a process where, instead of the 20 
policy documents presented and analyzed in this paper, an investment was made to engage with 20 groups of the most negatively affected and historically excluded voices in food and farming policy. In this case, the interests of such groups could be brought to bear on a food system that currently fails to meet their needs, yet continues despite the excessive harms it causes. The lifting of excluded voices in the production of policy discourse is, of course, only one important step, but one that must be taken if we are to take the process of collective reimagining seriously and move to a system that places long-term human flourishing above shortterm profit.

\section{References}

Agyeman, J. (2013). Introducing just sustainabilities: Policy, planning, and practice. New York, NY: Zed Books.

Alkon, A. H., \& Agyeman, J. (Eds.). (2011). Cultivating food justice: Race, class, and sustainability. Cambridge, MA: MIT Press.

Alkon, A. H., \& Norgaard, K. M. (2009). Breaking the food chains: An investigation of food justice activism. Sociological Inquiry, 79(3), 289-305. https://doi.org/10.1111/j.1475-682X.2009.00291.x

Allen, P., FitzSimmons, M., Goodman, M., \& Warner, K. (2003). Shifting plates in the agrifood landscape: The tectonics of alternative agrifood initiatives in California. Journal of Rural Studies, 19(1), 61-75. https://doi.org/10.1016/S0743-0167(02)00047-5

Anderson, C. R. (2017). Policy from below: Politicising urban agriculture for food sovereignty. Urban Agriculture Magazine, 33. https://ruaf.org/assets/2019/11/Urban-Agriculture-Magazine-no.-33-Urban-Agroecology.pdf

Anderson, C. R., Bruil, J., Chappell, M. J., Kiss, C., \& Pimbert, M. P. (2019). From transition to domains of transformation: Getting to sustainable and just food systems through agroecology. Sustainability, 11(19). https://doi.org/10.3390/su11195272

Anderson, C. R., Kay, C. S., Saxena, L. P., Kneafsey, M., Maughan, C., \& Tornaghi, C. (2016). Grassroots responses to food poverty in Coventry. Centre for Agroecology, Water \& Resilience (CAWR), Coventry University. https://doi.org/10.13140/rg.2.2.11202.84161

Anderson, C. R., Maughan, C., \& Pimbert, M. P. (2018). Transformative agroecology learning in Europe: Building consciousness, skills and collective capacity for food sovereignty. Agriculture and Human Values, 36, 531-547. https://doi.org/10.1007/s10460-018-9894-0

BBC News. (2019, May 22). Poverty in the UK is 'systematic' and 'tragic', says UN special rapporteur. BBC News. Retrieved from https://www.bbc.com/news/uk-48354692

Bradley, K., \& Herrera, H. (2016). Decolonizing food justice: Naming, resisting, and researching colonizing forces in the movement. Antipode, 48(1), 97-114. https://doi.org/10.1111/anti.12165

Cadieux, K. V., \& Slocum, R. (2015). What does it mean to do food justice? Journal of Political Ecology, 22(1). https://doi.org/10.2458/v22i1.21076

Candel, J. J. L., \& Pereira, L. (2017). Towards integrated food policy: Main challenges and steps ahead. Environmental Science \& Policy, 73, 89-92. https://doi.org/10.1016/j.envsci.2017.04.010

Centre for Policy Studies (CPS). (2017). Pointmaker: Brexit, agriculture, and agricultural policy. Retrieved from https://www.cps.org.uk/files/reports/original/170104093344-PostBrexitAgriculturalPolicy.pdf

Chiapello, E., \& Fairclough, N. (2002). Understanding the new management ideology: A transdisciplinary contribution from critical discourse analysis and new sociology of capitalism. Discourse \& Society, 13(2), 185-208. https://doi.org/10.1177/0957926502013002406

Compassion in World Farming (CIWF). (2017). Sowing fresh seeds: Food, farming and animal welfare post Brexit. Retrieved from https://www.ciwf.org.uk/media/7429843/food-farming-animal-welfare-post-Brexit-compassion-in-world-farmingjanuary-2017.pdf

Countryside Alliance. (2017). Brexit policy document: Sustaining a living and working countryside outside of the European Union. Retrieved from Countryside Alliance website: https://www.countrysidealliance.org/CountrysideAlliance/Media/News/2017/05/CA PolicyDocument Brexit Downloadable-PDF.pdf 
Defra. (2018a). Health and harmony: The future for food, farming and the environment in a Green Brexit. Retrieved from https://assets.publishing.service.gov.uk/government/uploads/system/uploads/attachment data/file/684003/futu re-farming-environment-consult-document.pdf

Defra. (2018b). Once-in-a-generation opportunity to shape future farming policy. Retrieved July 5, 2019, from https://www.gov.uk/government/news/once-in-a-generation-opportunity-to-shape-future-farming-policy

Devlin, S. (2016). Agricultural labour in the UK. London: Food Research Collaboration. Retrieved from https://foodresearch.org.uk/publications/agricultural-labour-in-the-uk/

Dowler, E., \& Jones Finer, C. (Eds.). (2003). Welfare of food: Rights and responsibilities in a changing world. Oxford: Blackwell.

Dowler, E., \& Lambie-Mumford, H. (2015). Introduction: Hunger, food and social policy in austerity. Social Policy and Society, 14(3), 411-415. https://doi.org/10.1017/S1474746415000159

Eating Better. (2017). Beyond the CAP: Policies to support better UK meat and dairy production post-Brexit. Retrieved from https://www.eating-better.org/uploads/Documents/2017/Beyond the CAP report.pdf

Fabian Society. (2015). Hungry for change: The final report of the Fabian Commission on food and poverty. Retrieved from https://www.fabians.org.uk/wp-content/uploads/2015/10/Hungry-for-Change-web-27.10.pdf

Fairclough, N. (2010). Critical discourse analysis: The critical study of language (2nd ed.). London: Routledge.

Fairclough, N, \& Fairclough, I. (2012). Analysis and evaluation of argumentation in critical discourse analysis: Deliberation and the dialectic of enlightenment. Argumentation et Analyse Du Discours, 9(2), 1-27.

Fairlie, S. (2017). Farming policy after Brexit: A report for the Greens. Report commissioned by Molly Scott Cato, Green MEP. Retrieved from http://mollymep.org.uk/2017/02/20/fairlie/

Farmer's Weekly. (2015, January 7). Pay survey: Who gets what in the farm industry. Retrieved April 27, 2018, from http:/ / www.fwi.co.uk/business/pay-survey-who-gets-what-in-the-farm-industry.htm

Food and Agriculture Organization of the United Nations (FAO). (2006). Policy brief: Food security. Retrieved from the ReliefWeb website: https://reliefweb.int/report/world/policy-brief-food-security

Food and Drink Federation (FDF). (2017). FDF manifesto 2017. Retrieved from https://www.fdf.org.uk/corporate pubs/FDF\%20Manifesto $\% 202017$.pdf

Gibson-Graham, J. K. (2006). A postcapitalist politics. Minneapolis: University of Minnesota Press.

Global Justice Now. (n.d.). The six pillars of food sovereignty. Retrieved July 5, 2019, from https://www.globaljustice.org.uk/six-pillars-food-sovereignty

GM Freeze. (2017). GM Freeze Briefing-Brexit and GM. https://www.gmfreeze.org/wpcontent/uploads/2017/11/Brexit-and-GM-GMFreeze-briefing.pdf

Gottlieb, R., \& Joshi, A. (2010). Food justice. Cambridge, MA: MIT Press.

Guthman, J. (2008). "If they only knew": Color blindness and universalism in California alternative food institutions. The Professional Geographer, 60(3), 387-397. https://doi.org/10.1080/00330120802013679

Heasman, M., \& Morley, A. (2017). Earning a crust? A review of labour trends in UK food manufacturing. Retrieved from the Food Research Collaboration website: https:// foodresearch.org.uk/publications/review-of-labour-trends-uk-food-manufacturing/

Holt-Giménez, E., \& Shattuck, A. (2011). Food crises, food regimes and food movements: Rumblings of reform or tides of transformation? The Journal of Peasant Studies, 38(1), 109-144. https://doi.org/10.1080/03066150.2010.538578

Holt-Giménez, E., \& Wang, Y. (2011). Reform or transformation? The pivotal role of food justice in the U.S. food movement. Race/Ethnicity: Multidisciplinary Global Contexts, 5(1), 83-102. https://doi.org/10.2979/racethmulglocon.5.1.83

Horst, M. (2017). Food justice and municipal government in the USA. Planning Theory \& Practice, 18(1), 51-70. https://doi.org/10.1080/14649357.2016.1270351

House of Lords (HoL). (2017). Brexit: Agriculture (20th Report of Session 2016-17: House of Lords Paper 169). Retrieved from https://publications.parliament.uk/pa/ld201617/ldselect/ldeucom/169/16902.htm

International Organization for Migration (IOM). (2018). World migration report 2018. Retrieved from https://www.iom.int/sites/default/files/country/docs/china/r5 world migration report 2018 en.pdf 
International Panel of Experts on Sustainable Food Systems (IPES-Food). (2019). Towards a common food policy for the European Union. Retrieved from http://www.ipes-food.org/ img/upload/files/CFP FullReport.pdf

Kneafsey, M., Owen, L., Bos, E., Broughton, K., \& Lennartsson, M. (2017). Capacity building for food justice in England: The contribution of charity-led community food initiatives. Local Environment, 22(5), 621-634. https://doi.org/10.1080/13549839.2016.1245717

Landworkers' Alliance, The (LWA). (2017). Making food sovereignty a reality: Recommendations for post-Brexit agricultural policy. Retrieved from https://landworkersalliance.org.uk/publications/

Lang, T., Millstone, E., \& Marsden, T. (2017). A food Brexit: Time to get real-A Brexit briefing. Retrieved from University of Sussex Science Policy Research Unit website: http://sro.sussex.ac.uk/id/eprint/69300/1/Food $\% 20$ Brexit $\% 20$ Briefing $\% 20$ Paper $\% 20$ LangMillstoneMarsden $\% 2$ 016July2017.pdf

Levkoe, C. Z. (2006). Learning democracy through food justice movements. Agriculture and Human Values, 23(1), 89-98. https://doi.org/10.1007/s10460-005-5871-5

Lawrence, F. (2019, September 10). The real cost of cheap US chicken? Chlorination is just the start. The Guardian. Retrieved from https://www.theguardian.com/commentisfree/2019/sep/10/chlorination-cheap-us-chicken-brexit

Longo, P. (2016). Food justice and sustainability: A new revolution. Agriculture and Agricultural Science Procedia, 8, 31-36. https://doi.org/10.1016/i.aaspro.2016.02.005

Mama D \& Anderson, C. R. (2016, October 24). Decolonisation and food sovereignty in Europe thoughts from the edges. Retrieved from http://www.peoplesknowledge.org/discussions-on-decolonising-food-food-sovereignty-in-europe/

Mama D \& Anderson, C. R. (2018). Exploring food and social justice in the UK. Breadlines, 1(1). Retrieved from https://communityknowledgecentred.wordpress.com/food-justice/breadlines/

Mansell, K. (2017). Inquiry into trade post-Brexit [Briefing paper]. Commissioned by the All-Party Parliamentary Group on Agroecology (APPGA). Retrieved from https://agroecology-appg.org/wp-content/uploads/2018/01/APPG-onAgroecology-Inquiry-into-Trade-Post-Brexit-2.pdf

McCarthy, J., \& Prudham, S. (2004). Neoliberal nature and the nature of neoliberalism. Geoforum, 35(3), $275-283$. https://doi.org/10.1016/j.geoforum.2003.07.003

Monbiot, G., Grey, R., Kenny, T., Macfarlane, L., Powell-Smith, A., Shrubsole, G., \& Stratford, B. (2019). Land for the many: Changing the way our fundamental asset is used, owned and governed. Report commissioned by the Labour Party. Retrieved from https://landforthemany.uk/

Moragues-Faus, A. (2017). Problematising justice definitions in public food security debates: Towards global and participative food justices. Geoforum, 84, 95-106. https://doi.org/10.1016/j.geoforum.2017.06.007

National Farmers' Union (NFU). (2017). Policy statement: Next steps for agricultural policy- A new deal for society. Retrieved from https://www.nfuonline.com/assets/94338

National Trust. (n.d.). Fascinating facts and figures. Retrieved from July 2019 from https://www.nationaltrust.org.uk/lists/fascinating-facts-and-figures

National Trust. (2016). The future of our countryside. Retrieved from https://www.nationaltrust.org.uk/news/the-future-of-our-countryside

New Economics Foundation (NEF). (2017). Agricultural subsidies in the UK after Brexit: A progressive solution. Report commissioned by Global Justice Now. Retrieved from https://www.globaljustice.org.uk/sites/default/files/files/resources/postbrexitagsubsidies report web 1.pdf

Olsaretti, S. (2018). The Oxford handbook of distributive justice. Oxford Handbooks. https://doi.org/10.1093/oxfordhb/9780199645121.013.38

Patel, R., \& Moore, J. W. (2017). A bistory of the world in seven cheap things: A guide to capitalism, nature, and the future of the planet. University of California Press.

Paterson, O. (2017). UK agricultural policy post-Brexit. Report commissioned by UK 2020. Retrieved from https://www.owenpaterson.org/sites/www.owenpaterson.org/files/201704/UK\%202020\%20Agricultural $\% 20$ Policy $\% 20$ Post-Brexit.pdf 
People's Food Policy, A (PFP). (2017). A people's food policy: Transforming our food system. Retrieved from https://www.peoplesfoodpolicy.org

Pickard, J. (2019). Warning of threat to UK-EU trade deal from US food demands. Financial Times. Retrieved December 11, 2019, from https://www.ft.com/content/778b2d6c-e830-11e9-a240-3b065ef5fc55

Policy Exchange. (2017). Farming tomorrow: British agriculture after Brexit. London: Policy Exchange. Retrieved from https://policyexchange.org.uk/publication/farming-tomorrow/

Recanati, F., Maughan, C., Pedrotti, M., Dembska, K., \& Antonelli, M. (2018). Assessing the role of CAP for more sustainable and healthier food systems in Europe: A literature review. Science of the Total Environment, 653, 908-919. https://doi.org/10.1016/j.scitotenv.2018.10.377

RSA, The. (2019). Our future in the land-RSA report. Retrieved from https://www.thersa.org/discover/publications-and-articles/reports/future-land

Saxena, L. P., \& Tornaghi, C. (2018). The emergence of social supermarkets in Britain: Food poverty, food waste and austerity retail. Centre for Agroecology, Water \& Resilience (CAWR), Coventry University. Retrieved from https://pureportal.coventry.ac.uk/en/publications/the-emergence-of-social-supermarkets-in-britain-food-povertyfood

Sbicca, J. (2018). Food justice and the fight for global human flourishing. Local Environment, 23(11), 1098-1102. https://doi.org/10.1080/13549839.2018.1528444

Shrubsole, G. (2019). Who owns England? How we lost our green do pleasant land \&o how to take it back. London: William Collins.

Slocum, R. (2018). Must everything be called “food justice?” Local Environment, 23(11), 1103-1105. https://doi.org/10.1080/13549839.2018.1532402

Soil Association. (2017). The future of British farming outside the EU. Retrieved from https://mollymep.org.uk/wp-content/uploads/Soil-Association-FULL-Feb17.docx.pdf

Sustain. (2017). Beyond 2020: New farm policy [Briefing]. Retrieved from https://www.sustainweb.org/publications/beyond 2020 new farm policy/\#

Sustain. (2018). Why would anyone want to pick our crops? Securing decent pay and conditions for agriculture workers in England. Retrieved from https://www.sustainweb.org/publications/why_pick_crops_newreport/

Tenant Farmers Association (TFA). (2016). A post EU farming policy for Britain. http:/ /www.tfa.org.uk/wp-content/uploads/2016/04/16-June-30-Post-Brexit-Agricultural-Policy.pdf

Touffut, J.-P. (2006). Advancing public goods. Cheltenham: Edward Elgar Publishing.

Ulster Farmers' Union (UFU). (2017). Brexit: Options for a new domestic agricultural policy (UFU discussion document). Retrieved from https://content17.green17creative.com/media/99/images/full/Brexit-Discussion-3.pdf

Wakeford, T. (2018). Everyday experts: How people's knowledge can transform the food system. Centre for Agroecology, Water \& Resilience (CAWR), Coventry University. https://www.coventry.ac.uk/research/areas-of-research/agroecologywater-resilience/our-publications/everyday-experts-how-peoples-knowledge-can-transform-the-food-system/

Zondag, M.-J., Lauwere, C., Sloot, P., \& Pauer, A. (2015). Pilot project: Exchange programmes for young farmers. Retrieved from European Commission Directorate-General for Agriculture and Rural Development website: http://www.agrotypos.gr/images/stories/file/ereuna neoi agroteseu 4 2016.pdf 